\title{
The drainage pattern of Hansbreen and Werenskioldbreen, two polythermal glaciers in Svalbard
}

\author{
Anja Pälli, John C. Moore, Jacek Jania, \\ Leszek Kolondra \& Piotr Głowacki
}

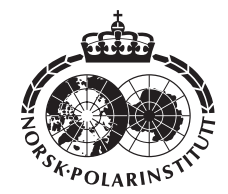

To improve our understanding of Svalbard-type polythermal glacier drainage, hydraulic geometry models of the subglacial hydrology of two contrasting glaciers in Svalbard have been constructed. The models are tested against a uniquely long and rich set of field observations spanning 45 years. Digital elevation models (DEMs) were constructed from bedrock data measured with ground penetrating radar and surface data of two medium-sized polythermal glaciers, Hansbreen and Werenskioldbreen, in south-west Spitsbergen. Hansbreen has a low angle bed with over-deepenings and a calving front, while Werenskioldbreen has steeper bed and terminates on land. Together they are representative of many Svalbard glaciers. The DEMs were used to derive maps of hydraulic potential and subglacial drainage networks. Validation of the models was done using field observations including location mapping and speleological exploration of active moulins, positions of main river outflows, dyetracing and water chemistry studies, and observations of water pressure inside moulins. Results suggest that the water pressure is generally close to ice overburden pressure but varies greatly depending on local conditions such as bed location, the thickness of cold ice layer, the thickness of the glacier and seasonal changes in meltwater input.

A. Pälli, Arctic Centre, University of Lapland, FI-96101 Rovaniemi, and Dept. of Geophysics, University of Oulu, FI-90014 Oulu, Finland, anjapa@luukku.com; J. C. Moore, Arctic Centre, University of Lapland, FI-96101 Rovaniemi, Finland; J. Jania \& L. Kolondra, Dept. of Geomorphology, University of Silesia, PL41-200 Sosnowiec, Poland; P. Gtowacki, Institute of Geophysics, Polish Academy of Sciences, PL-01-452 Warsaw, Poland.

Subglacial water pressure plays an important role in glacier dynamics (Paterson 1994; Jansson 1996; Bingham et al. 2001; Copland \& Sharp 2001). The response of Svalbard glaciers to climate change can only be accurately forecast if hydrological factors in ice dynamics are well understood. Polythermal glaciers in Svalbard have a layer of ice (cold ice) that is below the pressure melting point in their superimposed ice and ablation zones, usually underlain by ice that is at the pressure melting point (temperate ice) (e.g. Blatter \& Hutter 1991; see their Fig. $1 \mathrm{~b}-\mathrm{c})$. Their accumulation areas consist of temperate ice, except for the parts of the highest glaciers, where summer melt rates are relatively low and the firn is below freezing (Van de Wal et al. 2002). They may also be frozen to the bed in some places, especially near their fronts and margins. This results in a complex hydrological structure. In the accumulation area, waterflow down into the glacier body is slow, via the percolation and slow migration of water within the firn (Schneider 1999). In the ablation area, water can only penetrate through the impermeable cold ice layer via crevasses, moulins and fracture zones. Some meltwater is stored in the temperate layer 

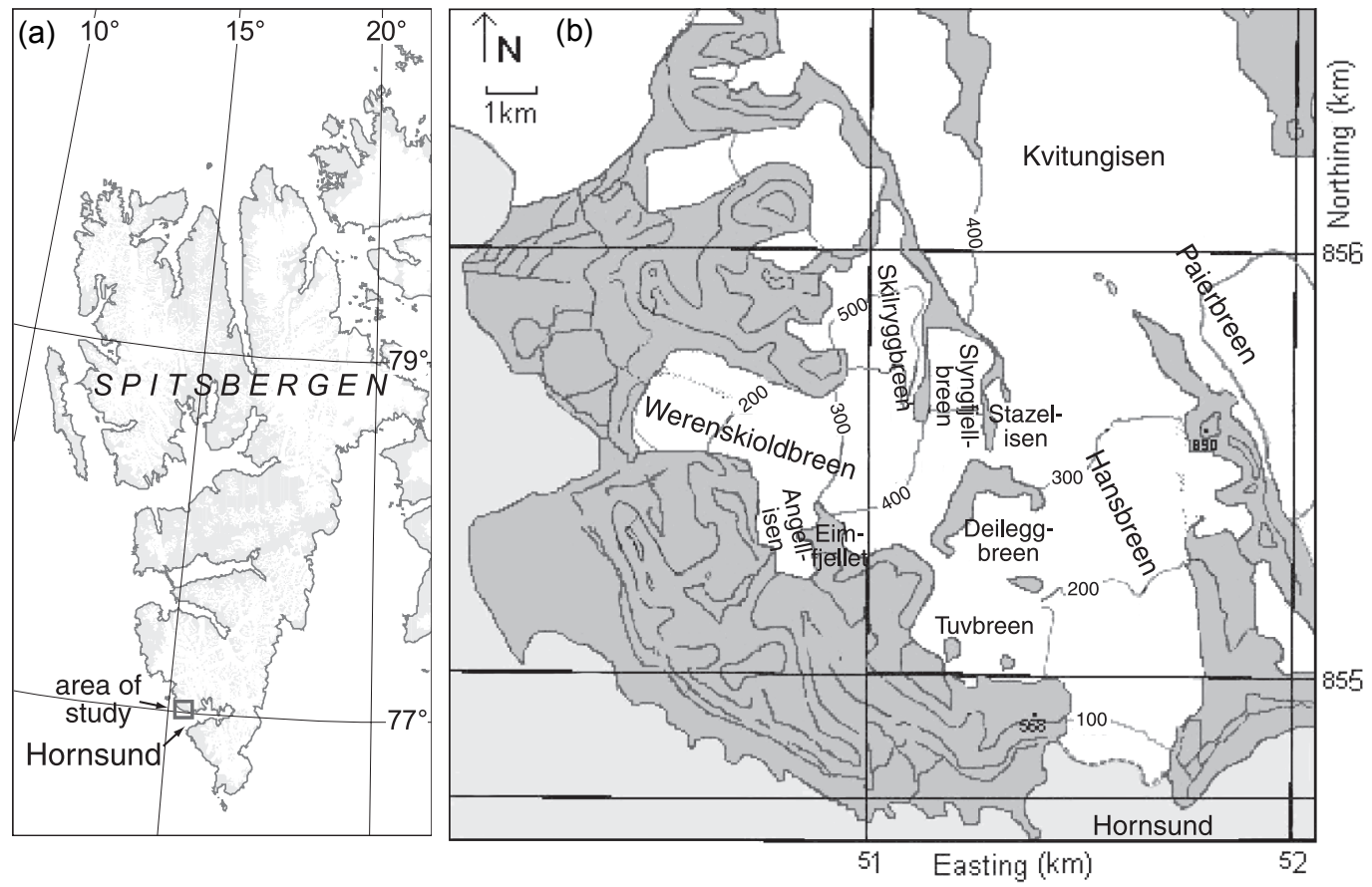

Fig. 1. (a) Map of Spitsbergen, indicating the location of the study area. (b) The area of Hansbreen and Werenskioldbreen (based on the Norwegian Polar Institute map Kystkart Svalbard 1:200000, sheet B4, Belsund. The coordinate system used in all figures is UTM Zone $33 \mathrm{X}$.

at all times, though the volume of water varies between winter and summer (Jania et al. 1996; Macheret \& Glazovsky 2000). The water content in the temperate layer of a Svalbard-type polythermal glaciers is higher than the typical water content of temperate glaciers (Macheret \& Glazovsky 2000). The water stored in the temperate layer can be enough to feed englacial runoff during the whole cold period (Macheret \& Glazovsky 2000). The englacial water eventually drains to flow at the glacier bed (Hodson et al. 1998; Wadham et al. 1998; Hodson \& Ferguson 1999; Skidmore \& Sharp 1999). The drainage network develops during summer, when surface melting and the subglacial system are in full operation (Hock \& Hooke 1993). Major channels in cold ice remain open during winter, so in Svalbard-type polythermal glaciers water outflow can continue throughout the year (Wadham et al. 2000). It is still not clear how water penetrates through the cold ice based regions around polythermal glacier snouts and margins (Wadham et al. 1998; Skidmore \& Sharp 1999). Surface melt may gain access through cold surface layers to warm areas of the glacier bed via moulins and crevasses (Skidmore \& Sharp 1999). On Finsterwalderbreen, cold basal ice at the terminus forces meltwater to take a subterranean routing in its latter stages (Wadham et al. 1998).

We have constructed digital elevation models (DEMs) of two polythermal glaciers: Hansbreen and Werenskioldbreen, in south-west Spitsbergen (Fig. 1). The DEMs were used to calculate hydraulic potential maps of the two glaciers. The hydraulic potential data were then used to model the flow network and drainage. Our objective was to model the hydraulic geometry and to provide insight into the drainage pattern and water pressures of the two glaciers.

\section{Field area}

\section{Hansbreen}

Hansbreen is a grounded tidewater glacier which flows into the fjord of Hornsund in southern Spitsbergen (Fig. 1). The glacier is about $16 \mathrm{~km}$ long and covers an area of $57 \mathrm{~km}^{2}$. The glacier tongue is about $2.5 \mathrm{~km}$ wide and terminates as a

The drainage pattern of two polythermal glaciers 
$1.5 \mathrm{~km}$ long calving front. The lateral parts of the front are based on land. The glacier extends from $600 \mathrm{~m}$ a.s.l. to sea level (Fig. 2) The maximum ice thickness is about $400 \mathrm{~m}$. The first $4 \mathrm{~km}$ up-glacier from the tongue has a reverse bed slope and the glacier bed lies below sea level as far as $10 \mathrm{~km}$ up-glacier from the terminus (Figs. 2a, 3a). However, the first ca. $600 \mathrm{~m}$ of the bed up-glacier from the terminus is about $50 \mathrm{~m}$ a.s.l. (Fig. 3a). The cold ice thickness varies from 20 to $90 \mathrm{~m}$ (Moore et al. 1999).

Mass balance has been measured since 1989 . Mean winter accumulation in 2000 was $0.93 \mathrm{~m}$ water equivalent (w.e.) and mean summer balance was $-1.14 \mathrm{~m}$ w.e., so the total net balance in 2000 was $-0.21 \mathrm{~m}$ w.e. In recent years the mean equilibrium line has varied between 320 and $370 \mathrm{~m}$ a.s.1. Hansbreen has a measured speed of $30 \mathrm{~m} \mathrm{a}^{-1}$ (1988) at the equilibrium line. The glacier flows significantly faster towards the terminal ice cliff, exceeding $210 \mathrm{~m} \mathrm{a}^{-1}$ near the terminus (Jania et al. 1996).

Ground penetrating radar (GPR) measurements of Hansbreen show the temperate ice layer to have $1-2 \%$ water content in general during winter, though areas associated with surface crevassing and moulins have water contents of 3-7\% (Moore et al. 1999). The water content in Hansbreen has also been observed to vary with depth: the upper part of the temperate layer is 2-3 times more water-saturated than the lower part (Macheret \& Glazovsky 2000). Speleological studies on Hansbreen have revealed large cavities, which consist of vertical shafts down to the depth of the cold/temperate ice boundary, connected to subhorizontal galleries below. These chambers are up to $10-15 \mathrm{~m}$ in diameter, and in some cases contain metre-scale water pools (Macheret \& Glazovsky 2000). In the cold/temperate ice transition zone at a depth exceeding $100 \mathrm{~m}$, smalldiameter conduits occur along with larger channels (Pulina \& Řehák 1991). On Hansbreen water outflows directly to the sea.

\section{Werenskioldbreen}

Werenskioldbreen is a land-based valley glacier next to Hansbreen but flowing from east to west (Fig. 1). It is divided by a massive moraine ridge (Fig. 2d) into Werenskioldbreen to the south and Skilryggbreen to the north. It covers an area of $27.4 \mathrm{~km}^{2}$ and is $9.5 \mathrm{~km}$ long. The glacier is situated between $0-600 \mathrm{~m}$ a.s.l. (Fig. 2d) and is very shallow; the thickest parts are 100-140 m thick and located in the central southern side and upper northern parts of the glacier. The snout is less than $50 \mathrm{~m}$ thick and the glacier is frozen to bedrock for $0.7-1 \mathrm{~km}$ upstream from the terminus (Fig. 3b). The cold ice layer thickness generally varies between $50-100 \mathrm{~m}$. Both the sides and some areas in the upper parts, where the glacier is less than $50 \mathrm{~m}$ thick, have cold ice down to the bed. Mass balance measurements were done in 1993/94 and 1998/99 and both net balances were negative: $-0.36 \mathrm{~m}$ w.e. and $-0.66 \mathrm{~m}$ w.e., respectively. The equilibrium line was noted at an elevation of ca. $350 \mathrm{~m}$ a.s.l. in 1994 and at ca. $470 \mathrm{~m}$ a.s.l. in 1999. Slow and relatively stable mean annual speeds have been noted near the glacier centreline (9.5-11 m/yr), with minor seasonal fluctuations (Jania 1988). Slightly higher surface speeds $(12-14 \mathrm{~m} / \mathrm{yr})$ were measured recently (2000-2001). The northern, steeper part of the glacier (Skillryggbreen) flows faster. Very low $(3.8 \mathrm{~m} / \mathrm{yr})$ speed has been measured near the cold-based glacier front, as a result of emergent flow with a significant vertical component (shear planes with thin morainic bands are visible on the surface at the glacier front).

\section{Methods}

\section{Ground penetrating radar}

In April 1998 we used a Ramac GPR (Malå Geoscience) with 25, 50 and $200 \mathrm{MHz}$ antennae to profile Hansbreen, Werenskioldbreen and some associated glaciers in Hornsund (see Moore et al. 1999 for details of techniques). The 25 and $50 \mathrm{MHz}$ data scans comprised 2048 samples in time windows of $5.55 \mu \mathrm{s}(25 \mathrm{MHz})$ and $5.09 \mu \mathrm{s}$ $(50 \mathrm{MHz})$. The $200 \mathrm{MHz}$ data were collected in the form of 1024 samples and a time window of $1.63 \mu \mathrm{s}$. The data were collected at $1.0 \mathrm{~m}(50 \mathrm{MHz}$ and $200 \mathrm{MHz})$ and at $3.0 \mathrm{~m}(25 \mathrm{MHz})$ intervals with triggering from an odometer wheel mounted behind the snowmobile. Scans were not stacked during data collection. The radar data were subsequently processed: amplitude zero-level correction was applied, background noise removed and vertical band pass filtering undertaken. Data were not migrated. This could introduce errors in bed slope and ice thickness. However, this is not likely to be a big problem since we use the data on roughly $100 \mathrm{~m}$ sized grid cells. Positioning was 

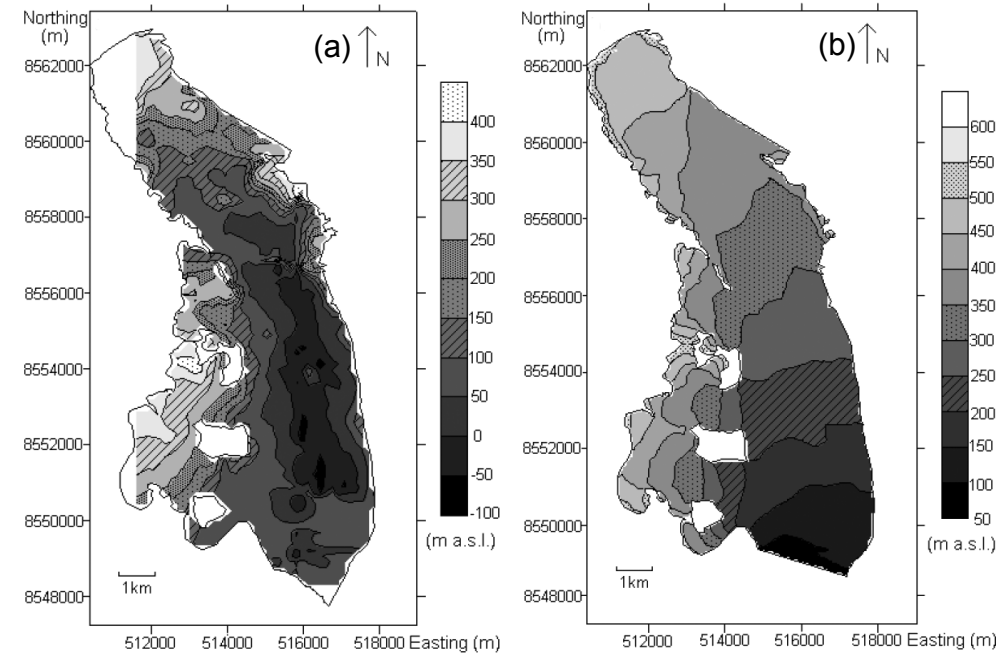

Fig. 2. (a) Hansbreen bedrock digital elevation model (DEM). (b) Hansbreen surface DEM. (c) Werenskioldbreen bedrock DEM. (d) Werenskioldbreen surface DEM showing the moraine ridge between Werenskioldbreen to the south and Skilryggbreen to the north.
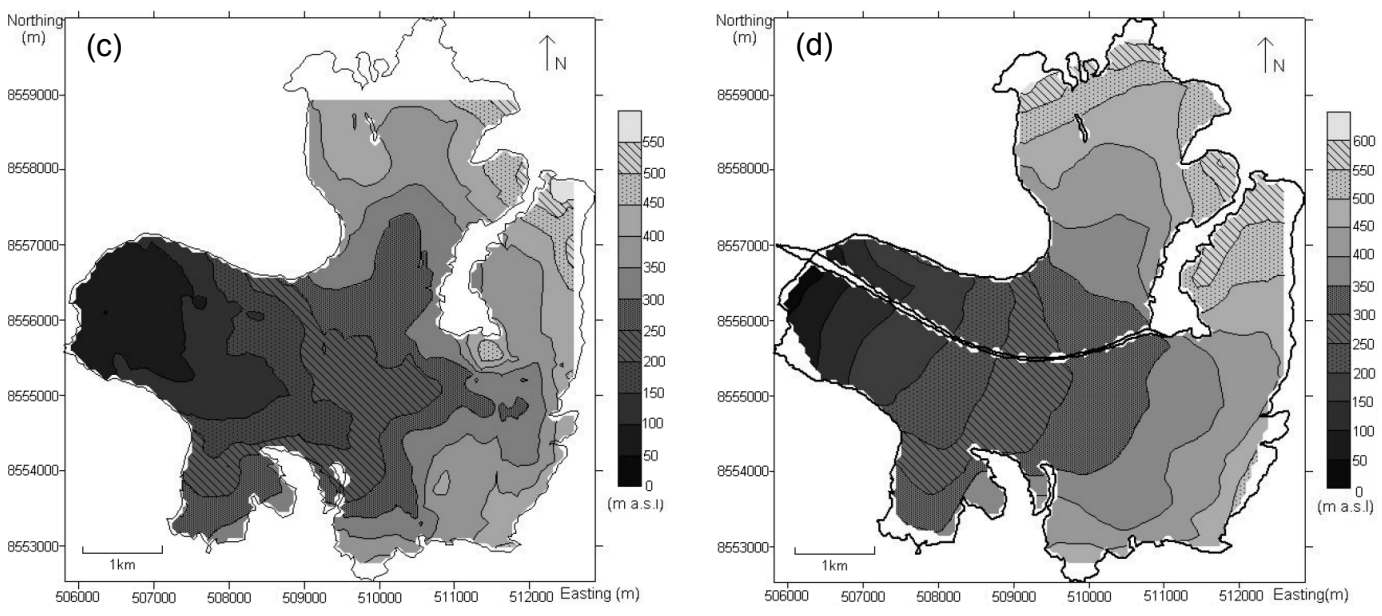

primarily from hand-held GPS, checked by passing close to several geodetically surveyed stakes as well as from the odometer wheel.

In addition to bedrock elevation, the GPR data were also used to locate areas of temperate ice within the glacier. Temperate ice has also been mapped with GPR on Hansbreen from several dozen discrete points in April 1989 (Glazovskiy et al. 1992; revised data in Kotlyakov 1992: 81) and from detailed studies of the radar wave velocity variations (Macheret et al. 1993). Higher frequency radar operating with much better spatial resolution was also used to map the internal structure in 1998 (Moore et al. 1999). Channels or crevasses within the glacier and the water content of the ice were mapped in many places based on

the travel time to point-scattering centres. These must have dimensions less than about half the radar wavelength in ice, so smaller than $2 \mathrm{~m}$ for $50 \mathrm{MHz}$ antennae and $0.5 \mathrm{~m}$ for $200 \mathrm{MHz}$ antennae, and can be seen as hyperbolic diffraction patterns in the radar data (Macheret et al. 1993; Pälli 1998; Moore et al. 1999).

\section{Digital elevation models}

DEMs of the glacier bed and surface may be used to calculate patterns of hydraulic potential across glacier beds (Shreve 1972). Hydraulic potential DEMs may then be used, with appropriate assumptions of water source availability, to delineate subglacial drainage catchments and 
determine the location and volume of the drainage network elements (Björnsson 1988; Holmlund 1988; Sharp et al. 1993; Fountain \& Vaughn 1995; Flowers \& Clarke 1999; Hagen et al. 2000; Copland \& Sharp 2001; Rippin et al. 2003).

Surface elevation data were collected using the GPS record of horizontal coordinates with photogrammetric maps from 1990 for each GPR measurement point. The surface elevation errors were estimated to be $\pm 15 \mathrm{~m}$ as a combination of GPS error and glacier surface height changes. Ice thickness data from GPR measurements produced 9463 measured points on Hansbreen and 7862 points on Werenskioldbreen. The ice thickness errors were estimated to be $\pm 5 \mathrm{~m}$. These data were used to calculate the hydraulic potential DEMs. Boundary data for Hansbreen and Werenskioldbreen were compiled from photogrammetric studies of aerial photos from 1990 and from differential GPS data collected in 1999. The GPR bedrock and GPS surface data sets were both linearly interpolated onto grids $(40 \times 100$ cells $157 \times 153 \mathrm{~m}$ in size for Hansbreen, and $100 \times 92$ cells $67 \times 67 \mathrm{~m}$ in size for Werenskioldbreen), and boundary files were used to "blank" the interpolated data beyond the glacier limits (Fig. 2).

\section{Model of the theoretical drainage}

Subglacial water flow is best indicated by potential energy gradients. To construct a potential surface map therefore requires knowledge of the actual water pressures everywhere. This is a difficult task to do since water pressure in a polythermal glacier changes in time and space (Jansson 1996). However, a theoretical subglacial drainage network can be constructed from surface and bed elevation data (Shreve 1972; Björnsson 1982, 1988; Sharp et al. 1993; Flowers \& Clarke 1999; Hagen et al. 2000; Copland \& Sharp 2001; Rippin et al. 2003). Gridded values of surface and bedrock elevation can be used to calculate the subglacial hydraulic potential to construct the subglacial drainage pattern from the total hydraulic potential $\Phi($ Shreve 1972; Björnsson 1982) given by:

$$
\Phi=\rho_{w} g z_{b}+K\left[\rho_{i} g\left(z_{s}-z_{b}\right)\right],
$$

where $\rho_{w}$ is the density of water $\left(1000 \mathrm{~kg} \mathrm{~m}^{-3}\right), \rho_{i}$ is the density of ice $\left(917 \mathrm{~kg} \mathrm{~m}^{-3}\right), g$ is the acceleration due to gravity $\left(9.81 \mathrm{~m} \mathrm{~s}^{-2}\right), z_{b}$ and $z_{s}$ are the elevations of bed and surface (m). Water-flow paths can be predicted by assuming a spatially
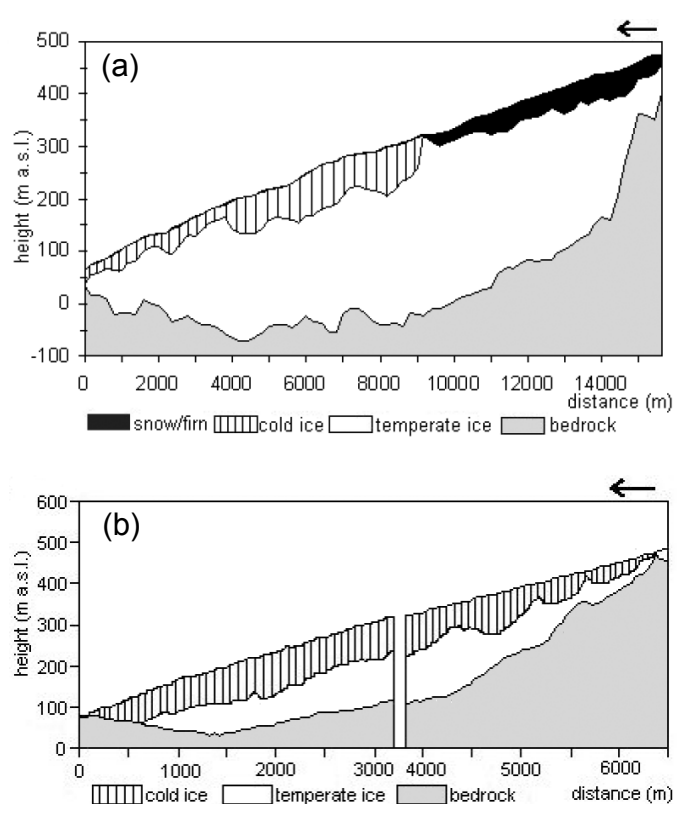

Fig. 3. Longitudinal profiles of (a) Hansbreen and (b) Werenskioldbreen. There is a small gap in (b) where we lack GPR data. Note that the gap width is not in scale. Flow direction is indicated with a black arrow in both figures.

uniform flotation fraction $K$, the ratio of water pressure/ice overburden pressure (Flowers \& Clarke 1999). We used three different values of $K$, to illustrate the drainage networks that may exist under Hansbreen and Werenskioldbreen. First, it is often assumed that the water pressure equals ice overburden pressure: $P_{w}=P_{i}$ or $K=1$. This might be the case in winter especially in overdeepenings when an efficient subglacial drainage system is not present (Flowers \& Clarke 1999; Hagen et al. 2000). However, it is well established from borehole water pressure measurements that in summer $P_{w}$ may drop below $P_{i}$ as a consequence of enlargement of drainage elements caused by surface meltwater input, but this condition cannot be maintained across the entire glacier bed (Flowers \& Clarke 1999). Therefore, we also considered the situation $P_{w}=0.5 P_{i}$ or $K=0.5$. Finally, if the ice is thin, the bed is steep and discharge is so high that tunnel melt rate exceeds closure rate of the subglacial drainage channels, the system may exist at atmospheric pressure: $P_{w}=P_{a}$ or $K=0$ (Hooke et al. 1984). This may occur in polythermal glaciers after high water input events at the end of summer when water has drained from enlarged channels and closure 
(a)
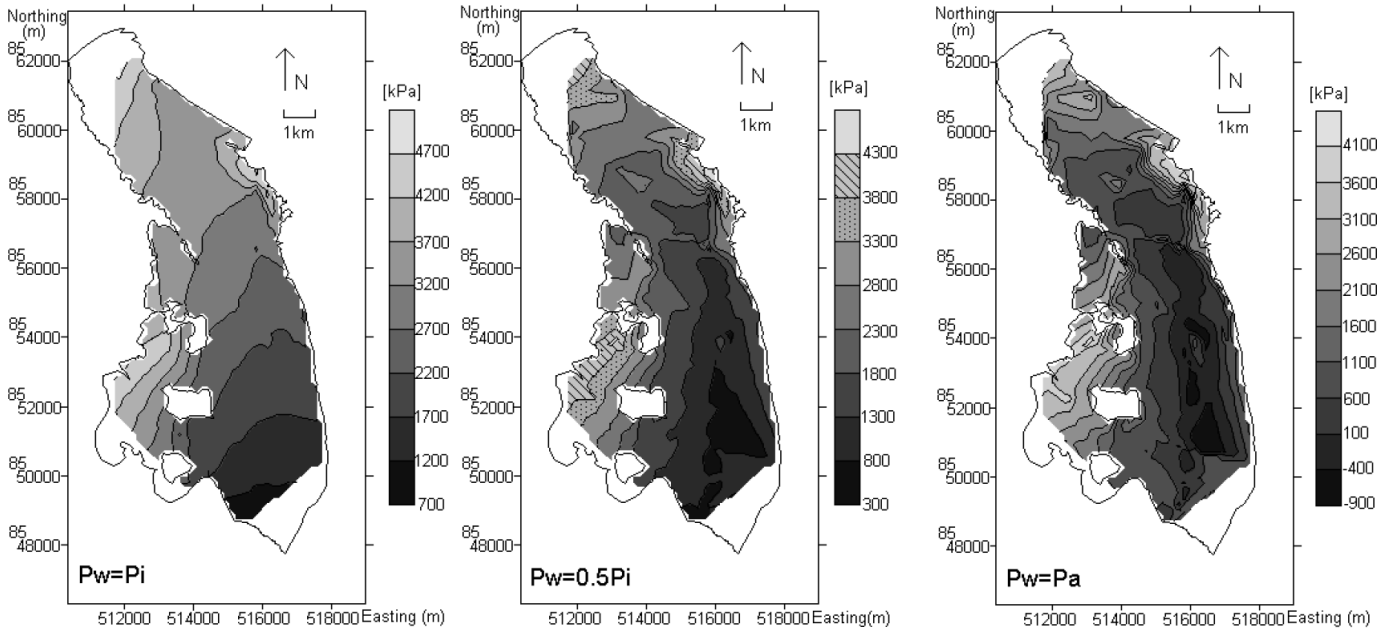

(b)
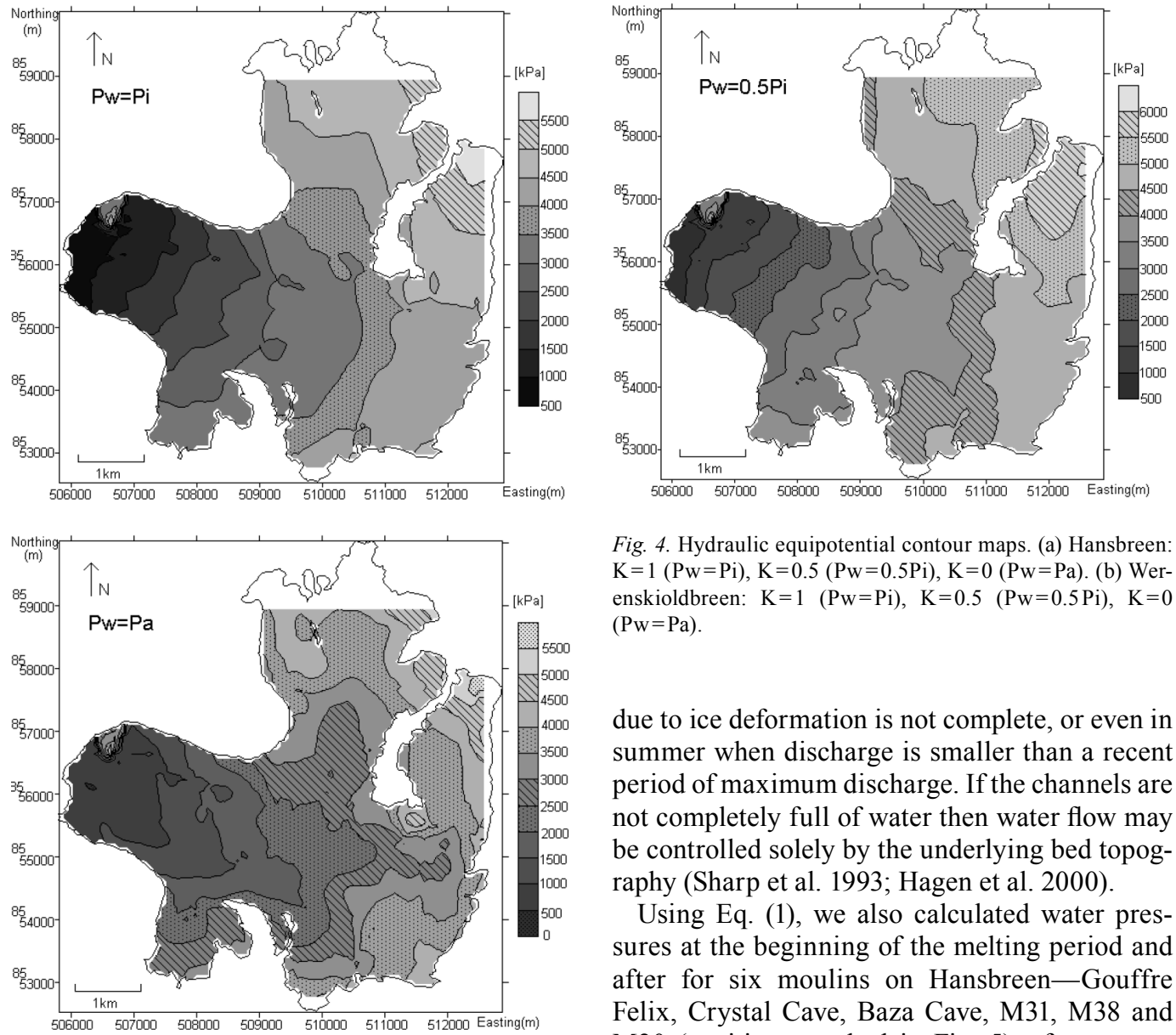

Fig. 4. Hydraulic equipotential contour maps. (a) Hansbreen: $\mathrm{K}=1(\mathrm{Pw}=\mathrm{Pi}), \mathrm{K}=0.5(\mathrm{Pw}=0.5 \mathrm{Pi}), \mathrm{K}=0(\mathrm{PW}=\mathrm{Pa})$. (b) Werenskioldbreen: $\mathrm{K}=1 \quad(\mathrm{Pw}=\mathrm{Pi}), \mathrm{K}=0.5 \quad(\mathrm{Pw}=0.5 \mathrm{Pi}), \mathrm{K}=0$ $(\mathrm{Pw}=\mathrm{Pa})$.

due to ice deformation is not complete, or even in summer when discharge is smaller than a recent period of maximum discharge. If the channels are not completely full of water then water flow may be controlled solely by the underlying bed topography (Sharp et al. 1993; Hagen et al. 2000).

Using Eq. (1), we also calculated water pressures at the beginning of the melting period and after for six moulins on Hansbreen-Gouffre Felix, Crystal Cave, Baza Cave, M31, M38 and M20 (positions marked in Fig. 5)-from water 
level measurements in September-October 1991 and May 1992 (Schroeder 1995).

\section{Estimation of the drainage pattern}

The idea of estimating the drainage pattern is to find how water collects to form subglacial channels, which combine to form bigger subglacial channels, leading to the subglacial drainage system. By using the water potential maps with the three values for $\mathrm{K}$ discussed above, a variety of drainage patterns can be estimated. To validate our modelling results for Hansbreen and Werenskioldbreen we have searched for field evidence to support these results.

First the upstream area for each of the three cases of $K$ was mapped to reconstruct the overall configuration of the subglacial drainage network (Sharp et al. 1993). The area of each grid cell was used as a substitute for the volume of runoff generated within one cell. Each grid cell has a "weight" defined as its own area plus that of any other cell that contributes runoff to it. A cold surface glacier like Hansbreen and Werenskioldbreen also promotes drainage along the lateral ice margin. This is allowed in the model as any cells can drain to any margin of the glacier. These resultant upstream maps should show the likely location of preferential drainage axes (Sharp et al. 1993).

We have used the TauDEM program (Tarboton $\&$ Ames 2001) to model the drainage pattern for Hansbreen and Werenskioldbreen. Pits in digital elevation data are defined as grid elements or sets of grid elements surrounded by higher terrain that, in terms of the DEM, do not drain (Tarboton $\&$ Ames 2001). These are often artefact errors in the DEM data but also happen in nature, as in Hansbreen, where we have a reverse bed slope to the snout. They are eliminated using a "flooding" approach that raises the elevation of each pit grid cell within the DEM to the elevation of the lowest pour point on the perimeter of the pit. We used two different methods of determining flow directions: the $\mathrm{D}_{8}$ and $\mathrm{D}_{\infty}$ methods. The $\mathrm{D}_{8}$ method (O'Callaghan \& Mark 1984) specifies flow directions by assigning flow from each grid cell to one of its eight neighbours, either adjacent or diagonally, in the direction with steepest downward slope. The $\mathrm{D}_{8}$ approach has disadvantages arising from the discretization of flow into only one of eight possible directions. In the $\mathrm{D}_{\infty}$ method, the flow direction angle measured counter-clockwise from east is represented as a continuous quantity between 0 and $2 \pi$ (Tarboton 1997). When the flow directions are solved the drainage area can be computed from the flow $\mathrm{D}_{8}$ directions. $\mathrm{D}_{\infty}$ flow direction data are used to calculate the specific catchment area but they can not yet be used for definition of the channel network (Tarboton \& Ames 2001).

\section{Results}

\section{Equipotential contours}

Hydraulic equipotential contours for $K=1,0.5$ or 0 for Hansbreen and Werenskioldbreen are shown in Fig. 4. Both the glaciers show similar results: when $K=1$, hydraulic potential contours are similar to surface contours (Fig. 2b); in the case of $K=0.5$, bed topography has a bigger influence on hydraulic potential than the surface. The influence of the bed topography (Fig. 2a) is therefore best seen when $K=0$ as subglacial water will tend to follow valley floors and cross divides at the lowest point.

\section{Theoretical drainage reconstruction}

Figures 5 and 6 show the results of the drainage networks and upstream area maps reconstructed by the $\mathrm{D}_{8}$ method, and the specific catchment area calculated by $\mathrm{D}_{\infty}$ for each case of $K$ for Hansbreen and Werenskioldbreen.

\section{Sensitivity of the models}

It is difficult to assess the impact of measurement errors in the modelled drainage network. However, as an example of what could be expected we consider a particular area of Hansbreen where our models deviated significantly from reality. The biggest outflow at the snout of Hansbreen is observed slightly east of the centreline (Fig. 7). None of the models predicts the place of the outflow exactly. This may well be because the outflow position is controlled by the glacier thermal regime and the potential hydraulic barrier that may exist around the frozen margin of the glacier. However, it may reflect deficiencies in the datawe lack ca $3 \mathrm{~km}^{2}$ bedrock data from the southeast corner of the glacier snout. The south-east corner is very crevassed and therefore impossible to access. To try to assess the sensitivity of 

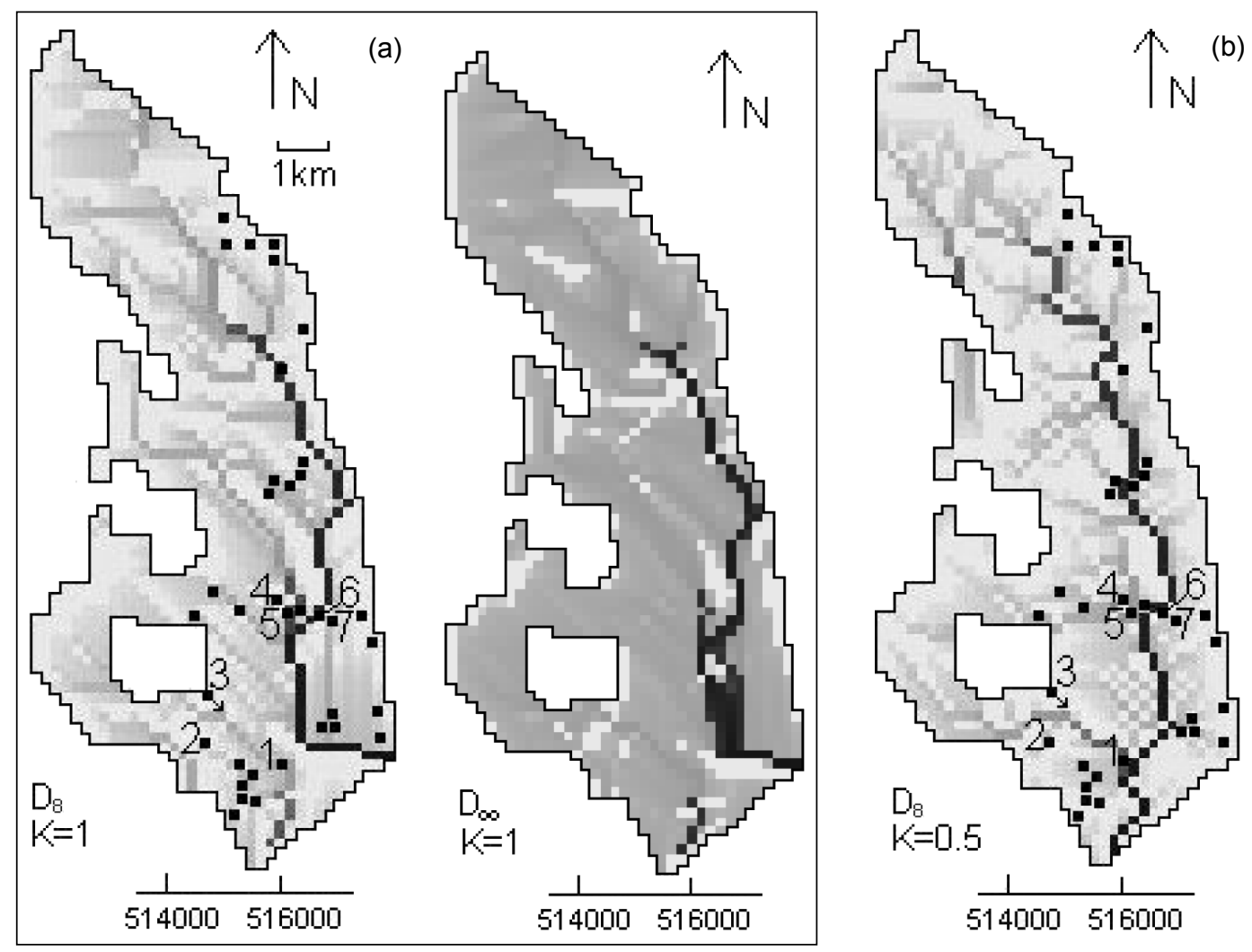

Fig. 5. Drainage maps of Hansbreen; plots of logarithmic upstream area. (a) $\mathrm{K}=1, \mathrm{D}_{8}$ flow directions and volume map, $\mathrm{D}_{\infty}$ main catchment map. (b, continued opposite page) $\mathrm{K}=0.5, \mathrm{D}_{8}$ flow direction and volume map, $\mathrm{D}_{\infty}$ main catchment map. (c, opposite page) $K=0, D_{8}$ flow directions and volume, $D_{\infty}$ maps main catchment map. Moulins are marked with black squares on $D_{8}$ maps, the moulins (see Table 1) are numbered: (1) Baza Cave, (2) M20, (3) Crystal Cave, (4) M31, (5) MVieli, (6) M38. (7) Gouffre Felix. The flow direction from Crystal Cave is marked with a black arrow.

the model to the missing bedrock data we ran the model with four different interpolated bedrock topographies in the south-east corner, together with surface data from aerial photographs and photogrammetric maps from 1990. For the bedrock interpolation we used bathymetry data from the seabed in front of the glacier and all available GPR data. The slope of the bed was changed in each of four interpolations by about $5^{\circ}$. We still could not produce the outflow in its real position. The best run that produced the outflow very close to the real position had a steeply reversesloping bed. With smooth bed models even with steep reversed slope we cannot precisely predict the position of the outflow. Therefore, we think that errors in DEMs of the magnitude we estimate are unlikely to cause gross changes in the drainage network modelled and that the outflow position might therefore be influenced by other fac- tors like the glacier thermal regime.

\section{Interpretation}

\section{Hansbreen}

The network drainage area $\left(D_{8}\right)$ and specific catchment area $\left(D_{\infty}\right)$ maps suggest that subglacial water flows from north-west to south-east and joins the main flow running in the eastern (Fig. 5a, b) or central (Fig. 5c) parts of the glacier. The main flow starts just above the firn line and divides into western and eastern branches in the accumulation area. The eastern branch has the bigger flow, with the western branch terminating at the edge of the glacier. In the accumulation area water flows to or from the adjacent Kvitungisen (Fig. 1) in the north-east (best seen

The drainage pattern of two polythermal glaciers 

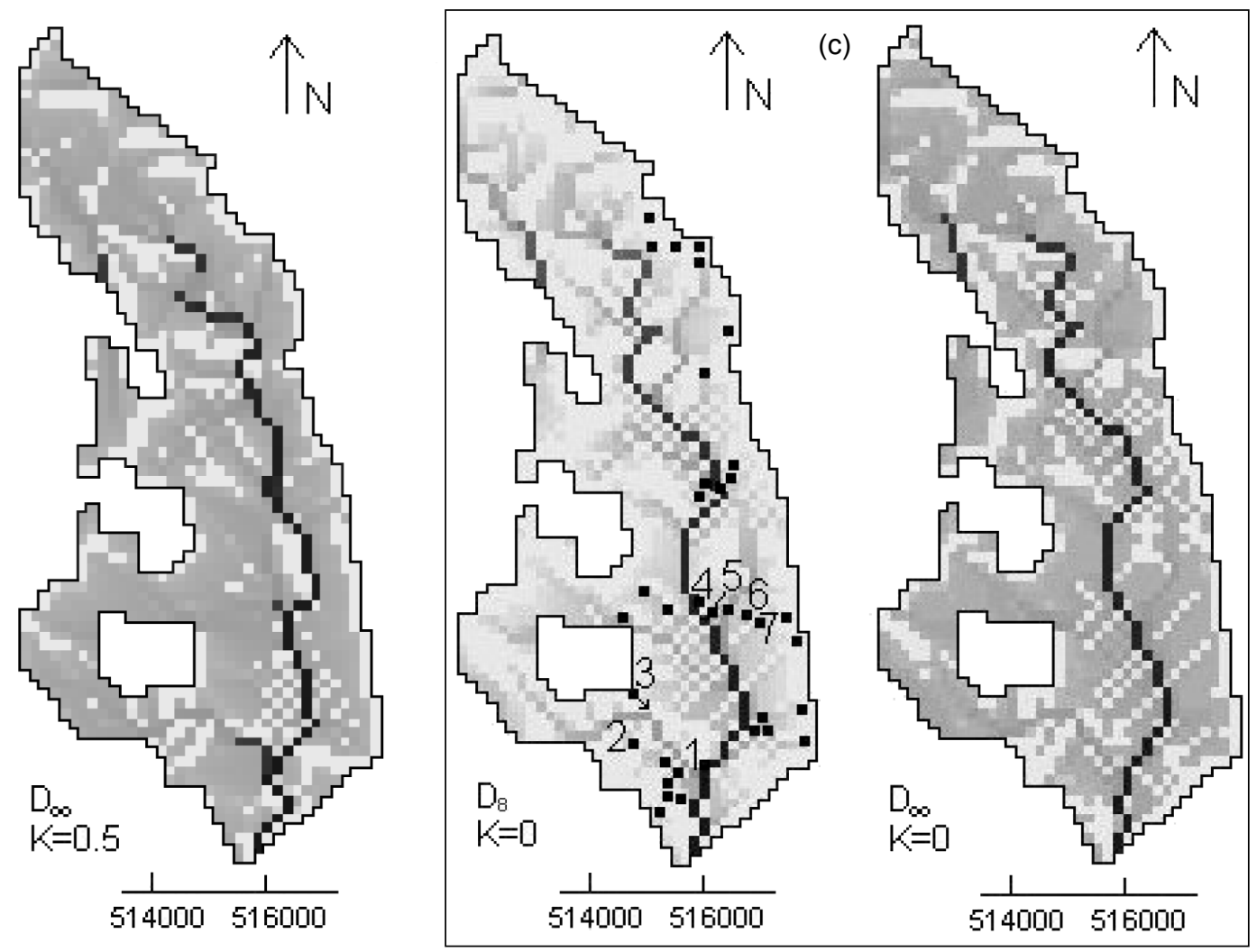

in the case $K=1$ (Fig. 5a), but it is also observable when water pressure is below the ice overburden pressure (Fig. 5b) or at atmospheric pressure (Fig. 5c). In the middle parts of the glacier, the biggest catchment seems to be on the eastern side, although in the case of $K=0$ the main catchment makes a gentle curve to the western side, but then curves back again to the eastern side closer to the front (Fig. 5c).

\section{Werenskioldbreen}

The network drainage area $\left(\mathrm{D}_{8}\right)$ and specific catchment area $\left(D_{\infty}\right)$ maps suggest two main catchments on Werenskioldbreen (Fig. 6). One seems to collect water from Skilryggbreen in the north and the other, flowing on the southern side of the glacier, collects water from Slyngfjellbreen in the north and the uppermost parts of Werenskioldbreen (Fig. 1). This is expected since Werenskioldbreen lies in two sub-basins separated by the medial moraine ridge (Fig. 2d), and both of them are temperate based. In the upper part of Werenskioldbreen, the main drainage path from the northern tributary Slyngfjellbreen follows the western margin in the $K=1$ and 0 models (Fig. $6 \mathrm{a}, \mathrm{c}$ ); in the $K=0.5$ model water from Slyngfjellbreen flows to the glacier sides (Fig. 6b). The flow from Skilryggbreen to Werenskioldbreen seems to be prevented because of the medial moraine, except for the case $K=0$ (Fig. 6c.). The $K=0.5$ model suggests a connecting channel from the south side (Werenskioldbreen) to the northern side (Skilryggbreen) underneath the medial moraine close to the front (Fig. 6b). The moulin locations are close to, or at, the biggest drainage axes in both the $K=0.5$ and $K=1$ models (Fig. $6 a, b)$.

The maps predict the central outflow in slightly different positions at the snout. For the case of $K=0.5$ both the main catchments seem to flow separately out in adjacent positions on the southern side of the medial moraine (Fig. 6b). A minor outflow from the northern side of the moraine ridge is predicted in all the models. The $K=1$ model also shows a southern outflow (Fig. 6a) that originates near the Angel Cave system on the southern margin. 

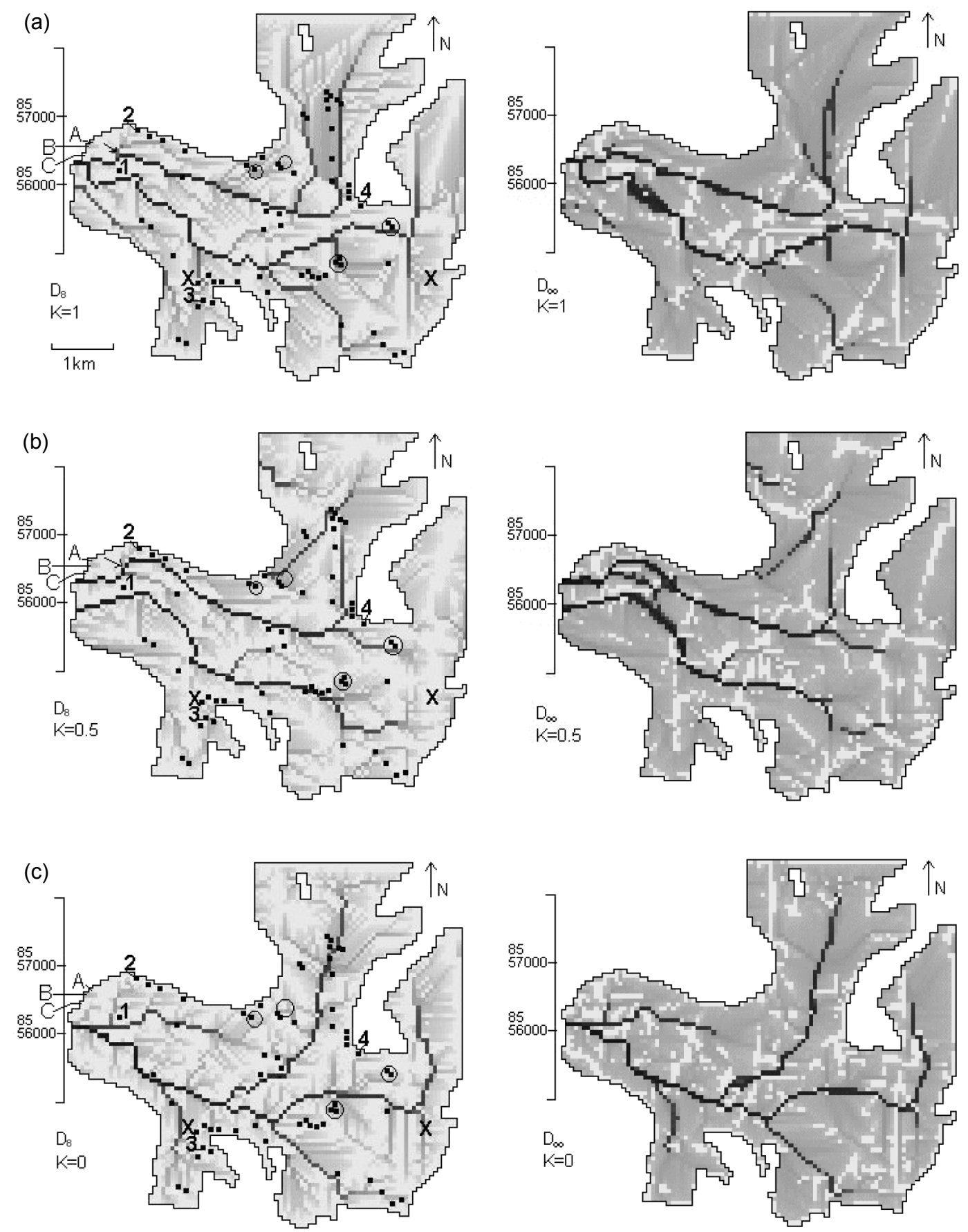

Fig. 6. Drainage maps of Werenskioldbreen; plots of logarithmic upstream area. (a) $\mathrm{K}=1, \mathrm{D}_{8}$ flow directions and volume map, $\mathrm{D}_{\infty}$ main catchment map. (b) $\mathrm{K}=0.5, \mathrm{D}_{8}$ flow directions and volume map, $\mathrm{D}_{\infty}$ main catchment map. (c) $\mathrm{K}=0, \mathrm{D}_{8}$ flow directions and volume map, $D_{\infty}$ main catchment map. Moulins are marked with black squares to $\mathrm{D}_{8}$ maps. Moulins mentioned in the text are numbered: (1) Lipertaven, (2) Kvisla Cave, (3) the moulin below Eimfjellet, (4) the moulin below Glasjologerknausen. The cryo-karst depressions are marked with circles and places of outbursts in the upglacier part with $\mathrm{X}$. The central outflow with three separate outflows is marked with A, B and C, and the Kvisla II spring, seen in cases (a) and (b), with a black arrow. 


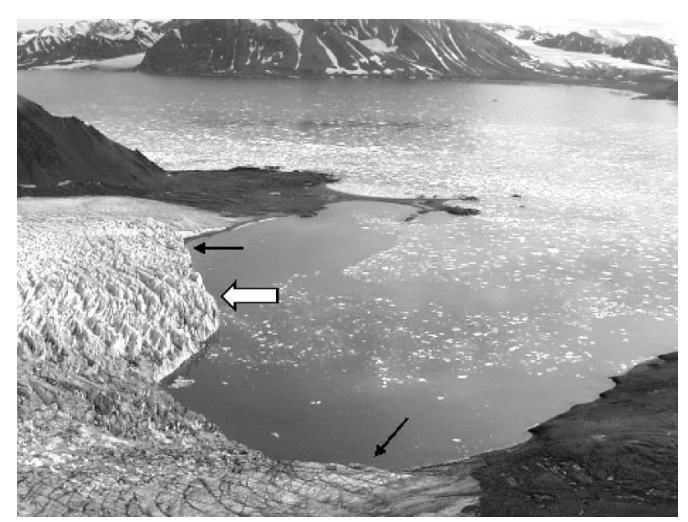

Fig. 7. Photograph of the snout of Hansbreen, showing the outflow locations in July 1999. The relative discharge of outflow is indicated by the size of the arrow.

\section{Discussion}

\section{Hansbreen: subglacial water}

We could not expect to see much of the subglacial channel system from the GPR survey, partly because all the data were collected during winter when many smaller channels may be closed, but most importantly because the channel network seems to be close to, or at, the bottom of the glacier. Our GPR measurements have shown that Hansbreen is not frozen to its bed and subglacial flow is possible everywhere.

In January 1999 a winter outflow from the lateral moraine next to the Hansbreen's snout was found and the specific electric conductivity (EC) of the water was measured every 5-6 days until the end of March. The measured EC values of the water were between 297-530 $\mu \mathrm{S} / \mathrm{cm}$ (M. Burzyk, pers. comm. 2002). This is much higher than for the ablation water from snow and ice (EC of $5-15$ $\mu \mathrm{S} / \mathrm{cm}$; Bukowska-Jania 2002). The high EC of the water is due to mineralization as a result of lengthy contact of subglacial water with till and bedrock underneath of a glacier (Bukowska-Jania 2002). During summer there has been noted an increase in mineralization of the water due to the subglacial component (Bukowska-Jania 2002). It therefore seems likely that water in Hansbreen flows subglacially all year (M. Burzyk, pers. comm. 2002).

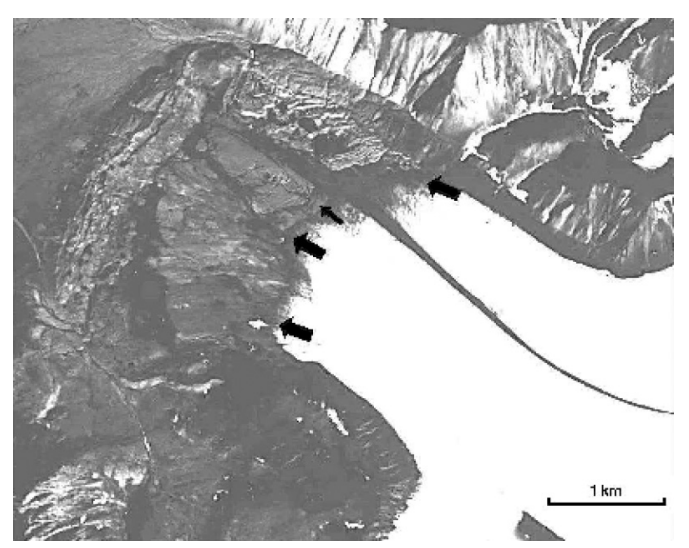

Fig. 8. Photograph of the snout of Werenskioldbreen, showing the outflow locations in 1990 (subset of aerial photograph S90 4071, printed with permission of the Norwegian Polar Institute). The relative discharge of out flow is indicated by the size of the arrow.

\section{Hansbreen: drainage network}

The drainage models suggest the main flow to be on the eastern side of the glacier and the general flow pattern to be from north-west to southeast (Fig. 5). We have traced a flow channel from Crystal Cave by mapping the individual hyperbolic reflections in the GPR traces collected in dense grid for about $200 \mathrm{~m}$ south-east, where it was lost (Fig. 5). This direction agrees well with the model water flow direction. Aerial photos of the glacier show that the most distinctive moulins (Fig. 5), thermokarst and collapsed features are close to the eastern lateral moraine, which provides supporting evidence for the modelled drainage pattern.

Water pressure calculations based on water level measurements in the six moulins can provide information about the water pressure in the subglacial drainage system if the moulins are connected to the bed or to a bigger subglacial channel close to the bed. GPR data showed that Crystal Cave and Baza Cave are connected to the bed. Deep reflections from Gouffre Felix, M31 and M38 were lost due to scattering from thick temperate ice layers. However their location in the middle of the glacier, and the big changes in water level observed, lead us to believe that they are connected to the subglacial system. The drainage models constructed suggest that all these moulins are situated close to the predicted subglacial channels (Fig. 5) and in local surface 
depressions. We have also marked other active moulins in the drainage maps (Fig. 5). Most of them are situated at, or near, the flow paths and are therefore likely connected to the drainage system driving supraglacial water to the subglacial system. This suggests that on Hansbreen surface melt water may gain access through the cold surface layer to temperate ice via moulins and crevasses.

\section{Hansbreen: water pressures}

The water pressure measured in six moulins (Table 1) indicates that water pressures differ in different parts of the glacier. Three of the moulins measured-Baza Cave, M38 and M31 - are situated in the centre of the over-deepened bedrock area (Figs. 2a, 5). They had water pressures close to $P_{i}$ both in the autumn and in the spring (Table 1). The bedrock has a reversed slope from M31 and M38 to Baza Cave and therefore they would require a high pressure system to overcome it. The three moulins are located in the immediate vicinity of predicted subglacial channels (Fig. 5 ). The modelled flow volume at the moulin surface location does not give information about the volume of water in the moulin. However, their location in the vicinity of predicted subglacial channels suggests that they are likely connected to the drainage system of Hansbreen channelling surface melt water through cold ice to the subgla- cial drainage network in the temperate ice.

In summer 1999 a field investigation looking at temporal and spatial variations in the flow velocities on Hansbreen was performed (Vieli 2001). Water level measurements of one moulin (called "MVieli" here), situated near M31 in the overdeepened bedrock part, were also made (Fig. 5, Table 1). During the melt season, short events with strongly increased surface velocities were observed in high resolution sub-diurnal velocity data (Vieli 2001). After this "speed-up" event the water pressure decreased rapidly from $0.85 P_{i}$ to $0.2 P_{i}$ (Table 1). Water pressure in summer can clearly vary greatly in the over-deepened bedrock part, depending on the meteorological conditions and therefore the amount of water input.

The Gouffre Felix moulin is situated where bedrock is just above sea level, on the edge of the over-deepened bedrock part (Figs. 2, 5). Calculations indicated that water pressure in autumn is closer to $0.5 P_{i}$ than ice over-burden pressure (Table 1). In spring, water pressure rose to $0.8 P_{i}$. The models suggest that the biggest water flow is west from Gouffre Felix at the overdeepened bedrock part (where pressures in the moulins there are high) (Fig. 5). The pressure drop in Gouffre Felix suggests that most water in autumn collects to the main flow channel and the enlarged channels on the sides are probably not full. During winter the channels almost close and in spring the pressure is high because the system

Table 1. Depth of water and calculated water pressures in M31, Gouffre Felix, Baza Cave, Crystal Cave, M20, M38 (Schröder 1995 ) and in MVieli (Vieli 2001) moulins on Hansbreen.

\begin{tabular}{|c|c|c|c|c|c|c|c|}
\hline \multirow{2}{*}{$\begin{array}{l}\text { Name of } \\
\text { moulin }\end{array}$} & \multicolumn{3}{|c|}{$\begin{array}{l}\text { Date of exploration and } \\
\text { depth of water level (m) }\end{array}$} & \multirow{2}{*}{$\begin{array}{c}\text { Difference in } \\
\text { water level (m) } \\
1991-92\end{array}$} & \multirow[t]{2}{*}{$\begin{array}{l}\text { Ice thick- } \\
\text { ness (m) }\end{array}$} & \multicolumn{2}{|c|}{ Water pressure $P_{w}$} \\
\hline & Sept. 1988 & Sept.-Oct. 1991 & May 1992 & & & Sept.-Oct. 1991 & May 1992 \\
\hline M31 & & 53 & 26 & +27 & 266 & $0.8 \mathrm{P}_{\mathrm{i}}$ & $0.9 \mathrm{P}_{\mathrm{i}}$ \\
\hline Gouffre Felix & $>120$ & 75 & 40.5 & +34.5 & 205 & $0.65 \mathrm{P}_{\mathrm{i}}$ & $0.8 \mathrm{P}_{\mathrm{i}}$ \\
\hline Crystal Cave & $>120$ & 52 & & & 148.9 & $0.45 \mathrm{P}_{\mathrm{i}}$ & \\
\hline M20 & & $>38$ & 19.5 & $>+20$ & $92.5^{\mathrm{a}}$ & $>0.8 \mathrm{P}_{\mathrm{i}}$ & $0.9 \mathrm{P}_{\mathrm{i}}$ \\
\hline M38 & & 15 & & & & $0.9 \mathrm{P}_{\mathrm{i}}$ & \\
\hline \multirow[t]{3}{*}{ Baza Cave } & & 21.5 (25 Sept.) & & & 160.4 & $0.8 \mathrm{P}_{\mathrm{i}}$ & \\
\hline & & 35.5 (27 Sept.) & & & & $0.75 \mathrm{P}_{\mathrm{i}}$ & \\
\hline & & 40.0 (28 Sept.) & 21 & +19 & & $0.7 \mathrm{P}_{\mathrm{i}}$ & $0.85 \mathrm{P}_{\mathrm{i}}$ \\
\hline \multirow[t]{4}{*}{ MVieli $^{b}$} & & 80 (12 July) & & 235 & & $0.6 \mathrm{P}_{\mathrm{i}}$ & \\
\hline & & 29 (16 July) & & & & $0.85 \mathrm{P}_{\mathrm{i}}$ & \\
\hline & & 160 (20 July) & & & & $0.2 \mathrm{P}_{\mathrm{i}}$ & \\
\hline & & 140 (26 July) & & & & $0.3 \mathrm{P}_{\mathrm{i}}$ & \\
\hline
\end{tabular}

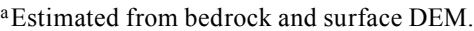

${ }^{\mathrm{b}}$ Explored in summer: 12-26 July1999. 
has not yet adjusted to the meltwater input from the surface.

Crystal Channel (Fig. 5) had low water pressure, close to atmospheric pressure, in the autumn (Table 1). The water drainage maps and GPR data indicate that Crystal Channel drains in a southeast direction. It seems that in the autumn, and probably already in late summer, the water supply may be insufficient to fill the channel and the pressure starts to drop. The channel from the moulin probably remains open, because we could trace it with GPR in winter. The glacier is quite shallow (about $140 \mathrm{~m}$ thick) here but half of it is cold ice. As the moulin fills with a plug of winter snow, the cold ice layer should keep it from melting, providing good insulation from the cold winter air for the channel in the temperate ice. The channel also has to be large (ca. $3 \mathrm{~m}$ minimum, because it can be resolved with $50 \mathrm{MHz}$ antennas) so that closure in winter is not complete, and most of the channel remains open. Unfortunately, there is no information on the water pressure in spring from Crystal Cave.

The bedrock and surface DEMs indicate that M20 probably collects water mainly from the western tributary glacier, Tuvbreen (Fig. 1). Table 1 shows that water pressure probably remains high all winter and, indeed, fairly high yearround. The glacier is shallow here, only about 90 $\mathrm{m}$, and there is no cold ice layer-the ice is probably under compression as the fairly steep Tuvbreen glacier meets the flatter Hansbreen around M20, perhaps allowing fairly rapid closure of drainage channels by ice deformation. M20 is seen in the $K=1$ model as a high connection probability (darker area), with its possible outflow to southeast (Fig. 5a).

\section{Hansbreen: outflow site}

On Hansbreen water outflow is from the east side of the tongue (Fig. 7). The observations were made from a boat since Hansbreen flows directly to the sea. This is a very strong outflow, containing a lot of sediments. There are also two minor outflows on both sides of the tongue, mainly transporting water from the surface. None of the models predicts the location of the outflow exactly: the models put the outflow slightly west from the centreline (Fig. 5b-c). This suggests that the outflow is governed by other factors, such as the hydraulic barrier provided by the frozen glacier periphery.

\section{Hansbreen: synthesis}

A necessary outcome of the type of model used here is a channelized drainage system, as all water in each discrete element flows down the steepest hydraulic gradient. Modelling a distributed drainage system would require parametrization of localized water flow mediated by icebedrock interactions, on which we have no data. We can, however use our modelling results to get an idea of the preferred drainage axes. It seems that the hydraulic geometry of Hansbreen probably varies between the two extremes $(K=1$ or $K=0$ ) of water pressure considered in the modelling, depending on the season. The over-deepening part (where bedrock is below sea level) seems to have high pressure close to the ice-overburden all winter. This is the area where large cavities $10-15 \mathrm{~m}$ in diameter and water pools have been observed (Macheret \& Glazovsky 2000). It seems that the pressure remains high all winter because the subglacial drainage system is not developed and the water is not able to escape from the cavities. The moulins indicate that channels on the lateral margins of the over-deepening are probably not fully filled in the autumn and therefore the water pressure drops. The pressure does not drop completely to atmospheric because of the closure of the channels. At the edges of the glacier, where bedrock is shallow but the cold ice layer thick, water pressure seems to drop close to atmospheric during winter. If ice flow is compressive, as is probably the case at M20, channels refreeze in winter, and therefore the water pressure is at iceoverburden. In summer, meteorological conditions seem to rapidly affect the water pressure in the over-deepened bedrock area. The water pressure can change from ice overburden to close to atmospheric in as short a time as four days. This suggests that Hansbreen has a well developed drainage system in summer, that can rapidly adjust to large water volume changes.

\section{Werenskioldbreen: drainage network}

The hydrology of Werenskioldbreen has been well studied using traditional techniques (Leskiewicz et al. 1999). Positions of outflows, caves, moulins and other cryokarst forms have been well mapped and discussed by several authors (Głowicki 1982; Řehák et al. 1990; Krawczyk et al. 1997; Leszkiewicz et al. 1999; Pulina et al. 1999). The system of englacial circulation is well 
recognized by dye tracing experiments (Krawczyk et al. 1997). Small shallow surface basins (cryokarst depressions) are situated in the glacier's ablation area (Fig. 6). Supraglacial meltwater from these basins drains off to moulins, which are connected to a channel or resevoir system in the glacier interior and emerge as springs in the front (Pulina et al. 1999). The cryokarst depressions marked in Fig. 6 are best seen in the $K=1$ model as darker colour, presenting areas of high connection probability. Skilryggbreen (Fig. 1) is also seen as a high connection probability area in the $K=1$ model. High water pressure is expected since higher velocities than on Werenskioldbreen are measured every year from this location.

\section{Werenskioldbreen: water pressure}

Since we lack water level data from moulins in Werenskioldbreen, the water pressure discussion is based on geomorphologically established information on the hydrology of Werenskioldbreen. Four moulins:- Lipertaven, Kvisla Cave, the moulin below Eimfjellet and the moulin below Glasjologerknausen, studied by Řehák et al. (1990) — are situated close to possible flow paths or the biggest drainage axes in the constructed models (Fig. 6). These moulins have a stable position in surface depressions, and they have been explored and shown to be connected to the subglacial drainage system by dye tracing and descents into individual systems ( ̌rehák et al. 1990). In general all the moulins on the glacier are close to the drainage axes (Fig. 6). Most of the moulins (except the four previously mentioned) survive only one ablation period, before they are destroyed by glacier flow (Řehák et al. 1990).

Interconnection of systems between Werenskioldbreen and Skilryggbreen (Fig. 1) underneath the medial moraine is predicted in both the $K=1$ and $K=0.5$ models (Fig. 6). Dye tracing experiments (Řehák et al. 1990) have shown that water from Lipertaven moulin, situated on the southern side of the medial moraine, outflows from the northern side of the moraine (the Kvisla II spring, Fig. 6a, b).

The $K=0.5$ and $K=1$ models predict welldefined drainage from the part of Skilryggbreen that turns westward at the beginning of the moraine, joining the northern main drainage channel and terminating near the northern margin. The Kvisla cave system (Fig. 6) and its lateral channel seem to join the main channel in the models, and this is also observed to occur in summer, but it is probably not active every winter (Krawczyk et al. 1997).

The moulin below Eimfjellet, which is readily visible in the $K=1$ model (Fig. 6a), was explored to the glacier bottom (135 m depth) in October 1988 (Řehák et al. 1990). They found water still running inside the system, though there had been winter conditions outside for several weeks. This suggests that, at that time and place, water pressure was equal to atmospheric pressure. Dye tracing experiments showed that water from the moulin flows out from the central outflow (Fig. 6).

\section{Werenskioldbreen: outflows}

The largest outflow is at the foot of the central part of the glacier front. Smaller outflows are found on the southern part of the central glacier and a large outflow zone at the north-west corner of the Skilryggbreen tongue. The high mineralization of the outflow water, in particular the high concentrations of $\mathrm{HCO}_{3}^{-}, \mathrm{Ca}^{2+}$ and $\mathrm{Mg}^{2+}$ ions clearly indicate solution of underlying carbonate rocks, presumably the dolomites of the Bergnova formation, which form the foundation of the Wernerknatten and Glasjologerknausen massifs (Birkenmajer 1990). The differences in outflow location from year to year can been seen by comparing the outflow observed in 1998 (Pulina et al. 1999), marked in Fig. 6 with the 1991 position shown in Fig. 8.

Chemical analyses from the three outflows in different parts of the glacier foreland showed that the EC values of the water were between 199 and $615 \mu \mathrm{S} / \mathrm{cm}$ (M. Burzyk, pers. comm. 12002). This result, similar to EC measurements in Hansbreen discussed previously, indicates that in Werenskioldbreen water also flows subglacially. None of the models estimate the subglacial central outflow positions (A, B, C in Figs. 6, 8) correctly. Outflow $\mathrm{B}$, which is right on the southern side of the moraine, can be seen from the models (Fig. 6). The main northern drainage channel in the $K=0.5$ and $K=1$ models seems to outflow very close the observed outflow C. However, the observed pattern of outflows during summer agrees best with the $K=0.5$ model. The model has two parallel subglacial channels, with two major outflows at the front of the southern tongue (Fig. $6 b)$. This is in good agreement with the observations (Fig. 8).

The drainage pattern of two polythermal glaciers 
Geyser-like spouts of water have been observed upglacier from the Werenskioldbreen terminus (Fig. 6) during outburst events and reflect overflow from the flooded subglacial environment via fissures in the ice (Baranowski 1977). One outburst was critical in initiating the release of subglacial meltwater from the glacier, demonstrating the importance of the thermal regime in dictating basal hydrology (Wadham et al. 2001). This kind of outburst has been interpreted as arising from the progressive accumulation of subglacial meltwater behind a cold ice dam, with subsequent breaching of the dam when water pressures exceeded the ice overburden pressure (Goodwin 1988; Skidmore \& Sharp 1999). An outburst occurs when the water pressure of the trapped water in the bed overcomes ice-overburden pressure. The $K=1$ model does not show trapped water (no dark areas surrounded totally by light areas), nor do the GPR data indicate local bedrock minima in the outburst locations; it seems rather that the two outbursts upglacier from the terminus are well connected to the channel network. However, GPR data shows that close to the eastern outburst (Fig. 6), the glacier is frozen to the bed in ice thicknesses of 40-100 m. It seems possible during the melting period that the cold ice layer could prevent any water escaping in the downglacier direction and the trapped water eventually escapes as an outburst. At a second outburst location (Fig. 6), at the front of Angellisen, the glacier is not frozen to the bottom, but the cold ice layer is about $120 \mathrm{~m}$ thick and the temperate ice layer only about $30 \mathrm{~m}$ thick. The outbursts indicate that the volume of melt water is too high to be accommodated by the existing drainage system and temporary or sudden reorganization or re-establishment of the drainage system.

Big fountain-like outbursts $(0.5-2 \mathrm{~m}$ in height $)$ have also been observed in the glacier forefield (at the location of central flow: A, B, C in Fig. 6), such as "Black" spring (Krawczyk et al. 1997). This outburst contained large amounts of suspended material. Similar outbursts are observed every year in the forefield and indicate that subglacial water is restored in some places and is highly pressurized. This maybe expected since the glacier is frozen to its bed at the terminus. The occurrence of outbursts on Werenskioldbreen suggests that Eq. (1) might not govern water flow direction near the snout of the glacier (or the cold/warm ice transition) and it is therefore unlikely that the water outflow observations would corroborate the predicted outflow locations from the model.

\section{Werenskioldbreen: synthesis}

According our models, the Werenskioldbreen drainage system seems to be well channelized during the melting period and the models suggest a dendritic drainage system. The frozen terminus probably causes channel blocking and high water pressures behind the front that often cause outburst floods. The high mineralization of the outflow water and the cold basal front of the glacier suggests that the water might flow in subterranean channels close the terminus. Atmospheric water pressure found in the moulin below Eimfjellet shows that at the end of the ablation season water pressure is atmospheric in some areas. Werenskioldbreen is generally thin and has relatively steep bedslopes, so atmospheric pressure is reasonable. The $K=0.5$ model fitted best the overall drainage pattern observations. This might indicate, together with all other observations discussed here, that water pressure in Werenskioldbreen varies greatly from ice overburden during summer to atmospheric pressure in some places at the end of the ablation period. Since most of the moulins cease to exist after one ablation period, many of the channels freeze during winter. Water resevoirs also exist in winter since a vast naled ice (also known as aufeis) field is formed in front of the central outflow. Therefore, water pressure might be at ice overburden close to the front all winter.

\section{Conclusions}

We used digital elevation models and observational evidence to study the drainage of two polythermal glaciers: Hansbreen (a relatively flat bedrock, calving glacier) and Werenskioldbreen (with steeper, more alpine-like bedrock, terminating on land) in south-west Spitsbergen. We have shown that geometric quantities derived from DEMs (hydraulic potential and upstream area maps) can be used as mesoscale hydrological predictors. Water pressure in the glacier varies with ablation, weather conditions, geometry and possibly the cold ice thickness so that inside the glacier the pressure can vary from atmospheric to iceoverburden conditions. However the models give an insight into the basin-scale drainage structure of the glaciers, although they were unable to pre- 
dict exactly the outflow positions and the positions of the smaller drainage axes.

Modelling of polythermal glacier drainage can be improved by including subglacial physics and with better understanding of the role of the thermal regime. As for the Hansbreen and Werenskioldbreen drainage models, more field data, especially dye tracing measurements on Hansbreen and water level measurements on Werenskioldbreen, as well as borehole measurements of water pressures from both, should be collected to be able to better evaluate the modelling results.

Acknowledgements.-The Finnish Academy and the Thule Institute funded the radar development. J. J., L. K. and P. G. were supported by the University of Silesia and the State Committee for Scientific Research under the terms of grant no. 6-P04E-014-21 (led by J. J.). We thank the Institute of Geophysics (Polish Academy of Sciences), the Polish Polar Station in Hornsund and the Norwegian Polar Institute for logistical support. The TauDEM program used here was written by David G. Tarboton of Utah State University and is available at www.engineering.usu.edu/cee/faculty/dtarb/. We thank Dr Tarboton for his help with initial problems we experienced with the program. Jack Kohler (Norwegian Polar Institute), Peter Jansson (Stockholm University) and Marian Pulina (University of Silesia) gave advice and helpful comments. Wihuri Physics Laboratory, University of Turku, kindly granted A. P. office space. We also thank Jyri Salminen at Wihuri Physics Laboratory for help with Mathcad 6.0.

\section{References}

Baranowski, S. 1977: The subpolar glaciers of Spitsbergen seen against the climate of this region. Acta Universitatis Wratislaviensis. Results of investigations of the Polish Scientific Spitsbergen Expeditions 1970-1974. Acta Univ. Wratislav. 410.

Bingham, R., Nienow, P., Sharp, M., Boon, S. \& Heppenstall, K. 2001: Dye-tracer studies of the hydrology of a HighArctic polythermal valley glacier: implications for glacier motion. Paper presented at the 58th Eastern Snow Conference. Ottawa, Canada, 15-17 May.

Blatter, H. \& Hutter, K. 1991: Polythermal conditions in Arctic glaciers. J. Glaciol. 37, 261-269.

Birkenmajer, K. 1990: Hornsund, Spitsbergen, Geology 1: 75000 (thematic map). Geological map of the Hornsund area. Katowice, Poland: University of Silesia.

Björnsson, H. 1982: Drainage basins on Vatnajökull mapped by radio echo sounding. Nord. Hydrol. 13, 213-232.

Björnsson, H. 1988: Hydrological characteristics of the drainage system beneath a surging glacier. Nature 395, 771-774.

Bukowska-Jania, E. 2002: Rola systemu lodowcowego $w$ obiegu weglanu wapnia $w$ srodowisku przyrodniczym (na przykBadzie Svalbardu i mlodoglacjalnych obszarow Polski polnocno-zachodniej). (The role of glacier systems in the migration of calcium carbonate in the natural environment [with particular reference to Svalbard and the late-glacial areas in north-west Poland].) Prace Naukowe Uniwersytetu Slaskiego 2103. (In Polish, with English summary.) Katowice, Poland: University of Silesia.

Copland, L. \& Sharp, M. 2001: Mapping thermal and hydrological conditions beneath a polythermal glacier with radio-echo sounding. J. Glaciol. 47, 232-242.

Flowers, G. \& Clarke, G. K. C. 1999: Surface and bed topography of Trapridge Glacier, Yukon Territory, Canada: digital elevation models and derived hydraulic geometry. J. Glaciol.45, 165-174.

Fountain, A. G. \& Vaughn, B. H. 1995: Changing drainage patterns within South Cascade Glacier, Washington, USA, 1964-1992. Int. Assoc. Hydrol. Sci. Publ. 228, 379-386.

Glazovskiy, A. F., Kolondra, L., Moskalevskiy, M. Y. \& Jania, J. 1992: Studies on the tidewater glacier Hansbreen on Spitsbergen. Polar Geogr. Geol. 16, 243-252.

Głowicki, B. 1982: Some hydrological phenomena observed in the outflow from the Werenskiold glacier basin. Spitsbergen Expeditions IV. Acta Univ. Wratislav. 525, 49-56.

Goodwin, I. D. 1988: The nature and origin of a jökulhlaup near Casey Station, Antarctica. J. Glaciol. 34, 95-101.

Hagen, J.-O., Etzelmüller, B. \& Nuttal, A.-M. 2000: Runoff and drainage pattern derived from digital elevation models, Finsterwalderbreen, Svalbard. Ann. Glaciol. 31, 147-152.

Hock, R. \& Hooke, R. L. 1993: Evolution of the internal drainage system in the lower part of Storglaciären, Sweden. Geol. Soc. Am. Bull. 105, 537-546.

Hodson, A. J. \& Ferguson, R. I. 1999: Fluvial suspended sediment transport from cold and warm based glaciers in Svalbard. Earth Surf. Process. Landforms 24, 957-974.

Hodson, A. J., Tranter, M., Dowdeswell, J. A., Gurnell, A. M. \& Hagen, J.-O. 1998: Glacier thermal regime and suspended sediment yield: a comparison of two high Arctic glaciers. Ann. Glaciol. 24, 32-37.

Holmlund, P. 1988: Internal geometry and evolution of moulins, Storglaciären, Sweden. J. Glaciol. 34, 221-233.

Hooke, R. L., Wold, B. \& Hagen, J.-O. 1984: Subglacial hydrology and sediment transport at Bondhusbreen, southwest Norway. Geol. Soc. Am. Bull. 96, 388-397.

Jania, J. 1988: Dynamiczne procesy glacialne na poludniowym Spitsbergen $w$ świetle badań fotointerpretacyjnych $i$ fotogrametrycznych. (Dynamic glacial processes in south Spitsbergen in the light of photointerpretation and photogrammetric research.) Prace Naukowe Uniwersytetu Ślaskiego 955. Katowice, Poland: University of Silesia.

Jania, J., Mochnacki, D. \& Gadek, B. 1996: The thermal structure of Hansbreen, a tidewater glacier in southern Spitsbergen, Svalbard. Polar Res. 15, 53-66.

Jansson, P. 1996: Dynamics and hydrology of a small polythermal valley glacier. Geogr. Ann. 78A, 171-180.

Kotlyakov, V. M. 1992: Rezhim I evolyutsiya polyarnykh lednikovykh pokrovov. (The regime and evolution of polar ice sheets.) St. Petersburg: Gidrometeoizdat.

Krawczyk, W. E., Pulina, M. \& Řehák, J. 1997: Similarity between the hydrologic system of the Werenskiold glacier (SW Spitsbergen) and karst. In P.-Y. Jeanin (ed.): Proceedings of the 12th International Congress of Speleology, 1997, Switzerland, Vol. 1. Pp. 493-496. Basel: Swiss Speleological Society.

Leszkiewicz, J., Piasecki, J. \& Pulina, M. 1999: Hydrology of

The drainage pattern of two polythermal glaciers 
the Werenskiold glacier catchment area (south Spitsbergen) in summer 1998. In J. Repelewska-Pekalowa (ed.): XXVI Polar Symposium, Lublin. Polish polar studies. Pp. 153160. Lublin: Maria Curie-Sklodowska.

Macheret, Y. Y. \& Glazovsky, A. F. 2000: Estimation of absolute water content in Spitsbergen glaciers from radar sounding data. Polar Res. 19, 205-216.

Macheret, Y. Y., Moskalevsky, M. Y. \& Vasilenko, E. V. 1993: Velocity of radio waves in glaciers as an indicator of their hydrothermal state, structure and regime. J. Glaciol. 39, 373-384.

Moore, J., Pälli, A., Ludwig, F., Blatter, H., Jania, J., Gadek, B., Głowacki, P., Mochnacki, D. \& Isaksson, E. 1999: Highresolution hydrothermal structure of Hansbreen, Spitsbergen, mapped by ground-penetrating radar. J. Glaciol. 45 , 524-532.

O'Callaghan, J. F. \& Mark, D. M. 1984: The extraction of drainage networks from digital elevation data. Comput. Vis. Graph. Image Process. 28, 328-344.

Pälli, A. 1998: Analysis and interpretation of ground penetrating radar data of polythermal glacier, Hansbreen, Svalbard. MSc thesis, University of Oulu, Finland.

Paterson, W. S. B. 1994: The physics of glaciers. Third edition. Oxford: Elsevier.

Pulina, M., Kolondra, L. \& Řehák, J. 1999: Charting of cryokarst forms on Werenskiold glacier (SW Spitsbergen). In J. Repelewska-Pekalowa (ed.): XXVI Polar Symposium, Lublin. Polish polar studies. Pp. 235-241. Lublin: Maria Curie-Sklodowska.

Pulina, M. \& Řehák, J. 1991: Glacier caves in Spitsbergen. In A. Eraso (ed.): 1st International Symposium of Glacier Caves and Karst in Polar Regions. Proceedings. Pp. 93117. Madrid: Geological Survey of Spain.

Řehák, J., Ouhrabka, V. \& Braun, J. 1990: New information about the interior drainage of subpolar glaciers and the structure of medial moraines of the southwest Spitsbergen. Stud. Carsologica 1, 15-56.

Rippin, D., Willis, I., Arnold, N., Hodson, A., Moore, J., Kohler, J. \& Björnsson, H. 2003: Changes in geometry and subglacial drainage of Midre Lovénbreen, Svalbard, determined from digital elevation models. Earth Surf. Process. Landforms 28, 273-298.

Schneider, T. 1999: Water movement in the firn of a polythermal glacier. J. Glaciol. 45, 286-294.
Schröder, J. 1995: Les moulins du glacier Hans de 1988 á 1992. (Moulins of Hansbreen from 1988 to 1992.) In M. Grieselin (ed.): Actes du 3e Symposium International, Cavités Glaciaires et Cryokarst en Régions Polaires et de Haute Montagne, 1-6 novembre 1994, Chamonix, France. Annales Littéraires de l'Université de Besançon 561, Série Géographie 34. Pp. 31-39. Paris: Les Belles Lettres.

Sharp, M., Richards, K., Willis, I., Arnold, N., Nienow, P., Lawson, W. \& Tison, J.-L. 1993: Geometry, bed topography and drainage system structure of the Haut Glacier D' Arolla, Switzerland. Earth Surf. Process. Landforms 18, 557-571.

Shreve, R. L. 1972: Movement of water in glaciers. J. Glaciol. 11, 205-214.

Skidmore, M. L. \& Sharp, M. 1999: Drainage system behaviour of a High-Arctic polythermal glacier. Ann. Glaciol. 28, 209-215.

Tarboton, D. G. 1997: A new method for the determination of flow directions and contributing areas in grid digital elevation models. Water Resour. Res. 33, 309-319.

Tarboton, D. G. \& Ames, D. P. 2001: Advances in the mapping of flow networks from digital elevation data. Paper presented at World Water and Environmental Resources Congress, Orlando, Florida, May 20-24.

Van de Wal, R. S. W. Mulvaney, R., Isaksson, E., Moore, J. C., Pinglot, J.-F., Pohjola, V. \& Thomassen, M. P. A. 2002: Reconstruction of the historical temperature trend from measurements in a medium-length bore hole on the Lonomosovfonna Plateau, Svalbard. Ann. Glaciol. 35, 371378.

Vieli, A. 2001: On the dynamics of tidewater glaciers. PhD thesis, Swiss Federal Institute of Technology, Zurich.

Wadham J. L., Hodson, A. J. Tranter, M. \& Dowdeswell, J. A. 1998: The hydrochemistry of meltwaters draining a polythermal-based High Arctic glacier, south Svalbard: I. The ablation season. Hydrol. Process. 12, 1825-1849.

Wadham, J. L., Hodgkins, R., Cooper, R. J., \& Tranter, M. 2001: Evidence for seasonal subglacial outburst events at a polythermal glacier, Finsterwalderbreen, Svalbard. Hydrol. Process. 15, 2259-2280.

Wadham, J. L., Tranter, M. \& Dowdeswell, J. A. 2000: Hydrochemistry of meltwaters draining a polythermal-based, High-Arctic glacier, south Svalbard: II. Winter and early Spring. Hydrol. Process. 14, 1767-1786. 